\title{
HAKIKAT PENDIDIK DAN ANAK DIDIK
}

\section{MUH. RIVALDI ANWAR, NURLINA, NURFAJRIANTI, NURFAIZA}

\section{Institut Agama Islam Muhammadiyah Sinjai}

\author{
nurlinafitriany@gmail.com
}

\begin{abstract}
ABSTRAK
Pendidik dan peserta adalah dua entitas yang tak dapat terpisahkan dalam menggerakkan dimensi pendidikan terutama pendidikan Islam. Kedunya mempunyai interaksi secara kontinyu yang dapat menghasilkan perambahan intelektual, namun tidak dapat dipungkiri dalam praktek pendidikan terkadang mengalami degradasi dan dekadensi bagi kalangan pendidik dengan mengesampingkan tradisi-tradisi humanis yang seharusnya diberlakukan dalam dimensi-dimensi peserta didik. Hal ini penting menjadi sebuah otokritik yang produktif dalam membangun tradisi pendidikan dengan mensejajarkan peserta didik tanpa adanya bentuk diskriminasi. Pendidik, peserta didik dan tujuan utama pendidikan merupakan komponen utama dalam pendidikan, ketiga komponen tersebut merupakan komponen yang satu jika hilang salah satu dari komponen tersebut maka hilang pula hakikat pendidikan tersebut.

Hakikat pendidik dan peserta didik inilah yang perlu menjadi bahan pengetahuan sebagai landasan untuk melakukan kegiatan transformasi ilmu pengetahuan kepada peserta didik yang merupakan sebagai obyek dalam penanaman nilai moral, sosial, intelektual, keterampilan dan spiritual. Pendidik merupakan pelaku utama dalam tujuan dan sasaran pendidikan yaitu membentuk manusia yang berkepribadian dan dewasa. Disamping sebagai tujuan pendidikan Islam secara umum diorientasikan untuk membentuk insan kamil, insankaffah,dan mampu menjadi khalifah Allah swt.
\end{abstract}




\section{BAB I}

\section{PENDAHULUAN}

\section{A. Latar belakang}

Pendidik dan peserta adalah dua entitas yang tak dapat terpisahkan dalam menggerakkan dimensi pendidikan terutama pendidikan Islam. Kedunya mempunyai interaksi secara kontinyu yang dapat menghasilkan perambahan intelektual, namun tidak dapat dipungkiri dalam praktek pendidikan terkadang mengalami degradasi dan dekadensi bagi kalangan pendidik dengan mengesampingkan tradisi-tradisi humanis yang seharusnya diberlakukan dalam dimensi-dimensi peserta didik. Hal ini penting menjadi sebuah otokritik yang produktif dalam membangun tradisi pendidikan dengan mensejajarkan peserta didik tanpa adanya bentuk diskriminasi. Pendidik, peserta didik dan tujuan utama pendidikan merupakan komponen utama dalam pendidikan, ketiga komponen tersebut merupakan komponen yang satu jika hilang salah satu dari komponen tersebut maka hilang pula hakikat pendidikan tersebut.

Hakikat pendidik dan peserta didik inilah yang perlu menjadi bahan pengetahuan sebagai landasan untuk melakukan kegiatan transformasi ilmu pengetahuan kepada peserta didik yang merupakan sebagai obyek dalam penanaman nilai moral, sosial, intelektual, keterampilan dan spiritual. Pendidik merupakan pelaku utama dalam tujuan dan sasaran pendidikan yaitu membentuk manusia yang berkepribadian dan dewasa. Disamping sebagai tujuan pendidikan Islam secara umum diorientasikan untuk membentuk insan kamil, insan kaffah,dan mampu menjadi khalifah Allah swt.

\section{B. Rumusan Masalah}

1. Apa yang dimaksud dengan pendidik dan anak didik 
2. Bagaimana interaksi paedagogik antara pendidik dan anak didik

\section{Tujuan Penulisan}

1. Untuk menegtahui apa yang dimaksud dengan pendidik dan anak didik

2. Untuk mengetahui Bagaimana interaksi paedagogik antara pendidik dan anak didik 


\section{BAB II \\ PEMBAHASAN}

\section{A. Pendidik dan anak didik}

Pendidikan merupakan hal yang tidak terlepas dari kehidupan kita seharihari. Pendidikan bagi manusia adalah melibatkan semua unsur dalam kehidupannya, baik unsur dari dalam dirinya sendiri yang sudah membawa potensi juga melibatkan unsur lain di luar dirinya yaitu lingkungan keluarga, masyarakat dan alam sekitarnya. Agar manusia itu mengetahui dan memiliki pemahaman akan eksistensi dirinya maka manusia itu perlu dididik sehingga berkembang sesuai dengan fitrahnya. Pendidik merupakan faktor penting dalam kegiatan kependidikan.

\section{Pendidik}

Kata pendidik berasal dari didik, artinya memelihara, merawat dan memberi latihan agar seseorang memiliki ilmu pengetahuan seperti yang diharapkan (tentang sopan santun, akal budi, akhlak, dan sebagainya) selanjutnya dengan menambahkan awalan pe- hingga menjadi pendidik, artinya orang yang mendidik. Dalam Kamus Umum Bahasa Indonesia, pendidik artinya orang yang mendidik.4 Secara etimologi dalam bahasa Inggris ada beberapa kata yang berdekatan arti pendidik seperti kata teacher artinya pengajar dan tutor yang berarti guru pribadi, di pusat-pusat pelatihan disebut sebagai trainer atau instruktur. ${ }^{1}$

Menurut kamus Besar Bahasa Indonesia Pendidik adalah orang yang mendidik. Pendidik adalah orang dewasa yang membimbing anak agar si anak tersebut bisa menuju kea rah kedewasan. Pendidik merupakan orang

\footnotetext{
${ }^{1}$ M. Ramli, Hakikat Pendidik dan Peserta Didik, TARBIYAH ISLAMIYAH, Vol. 5, No.
} 1, 2015. h. 62 . 
yang bertanggung jawab terhadap pelaksanaan pendidikan dengan sasarannya adalah anak didik. ${ }^{2}$

Dalam mencapai keberhasilan pendidikan, pendidik memiliki peran yang menentukan, sebab pendidik biasa dikatakan sebagai kunci utama terhadap kesuksesan pendidikan. Untuk itu seorang pendidik harus memenuhi persyaratan tertentu yang memadai, ciri-ciri yang berbeda dengan profesi yang lain.

Pendidik sebagai orang yang bertaggung jawab membimbing anak untuk mencapai kedewasaan, dibedakan kepada dua jenis, yaitu pertama pendidik karena keharusan atas kewajaran kehidupan, sedangkan yang kedua adalah pendidik karena diserahi tugas untuk mendidik anak.

Pendidik adalah individu yang mampu melaksanakan tindakan mendidik dalam situasi pendidikan untuk mencapai tujuan pendidikan. Oleh karena itu, seorang guru dituntut harus memiliki berbagai sifat dan sikap antara lain: ${ }^{3}$

1. Seorang guru harus manusia pilihan

2. Seorang guru hendaklah mampu mempersiapkan dirinya sesempurna mungkin.

3. Seorang guru juga hendaknya tidak pernah tamak dan bathil dalam melaksanakan tugasnya sehari-hari

4. Seorang guru hendaknya dapat menyakini Islam sebagai konsep Ilahi dimana dia hidup dengan konsep itu

5. Seorang guru harus memiliki sikap yang terpuji

6. Penampilan seorang guru hendaknya selalu sopan dan rapi

7. Seorang guru seyogyanya juga mampu menjadi pemimpin yang shalih

2 Dalam kamus Besar Bahasa Indonesia (KBBI) online. Tersedia https://kbbi.web.id/pendidik Diakses pada 14 Maret 2021.

${ }^{3}$ Zakiah Drajat, Metodik Khusus Pengajaran Agama Islam, (Jakarta; Bumi Aksara, 2001), h. 264. 
8. Seruan dan ajaran seorang guru hendaknya tercermin pula dalam sikap keluarganya dan atau para sahabatnya

9. Seorang guru harus menyukai dan mencintai muridnya

2. Anak didik

Peserta ddik adalah umat manusia yang diakui haknya sebagai individu dan mempunyai tanggung jawab sosial. Dengan demikian peserta didik dikatakan sebagai anak manusia yang tengah berkembang dengan pertolongan pendidik. Dalam UU No. 20 tahun 2003 tentang Sistem pendidikan Nasional, peserta didik adalah anggota masyarakat yang berusaha mengembangkan potensi diri melalui proses pembelajaran yang tersedia pada jalur, jenjang dan jenis pendidikan tertentu.

Peserta didik adalah anggota masyarakat yang berusaha mengembangkan potensi diri melalui proses pembelajaran pada jalur pendidikan baik pendidikan informal, pendidikan formal maupun pendidikan nonformal, pada jenjang pendidikan dan jenis pendidikan tertentu.

Perlu diketahui bahwa anak sebagai manusia yang sedang berkembang menuju ke arah kedewasaan memiliki beberapa karakteristik. Berikut 4 karakteristik yang dimaksudkan:

a. Individu yang memiliki potensi fisik dan psikis yang khas, sihingga merupakan makhluk unik.

b. Individu yang sedang berkembang.

c. Individu yang membutuhkan bimbingan individual dan perlakuan manusiawi

d. Individu yang memiliki kemampuan untuk mandiri.

Untuk mengetahui seorang anak didik maka kita perlu tahu bagaimana ciri-ciri anak didik tersebut. Berikut ciri-ciri anak didik:

a. Kelemahan dan ketidakberdayaan

b. Anak didik adalah makhluk yang ingin berkembang

c. Anak didik yang ingin menjadi diri sendiri 


\section{B. Interaksi pedagogik antara pendidik dan anak didik}

Interaksi terbagi atas dua kata yaitu inter dan aksi dimana inter ialah antar dan aksi ialah kegiatan. Jadi, interaksi adalah timbale balik yang saling memberikan rangsangan pada kegiatan. Sedangkan interaksi pendidik dan peserta didik merupakan suatu kegiatan pembelajaran yang dilakukan dalam interaksi belajar mengajar.

Interaksi secara umum ialah suatu hubungan dalam suatu kegiatan pembelajaran yang dilakukan peserta didik dan pendik untuk mencapai pendewasaan anak dan tercapai tujuan pendidikan, seperti interaksi social.

Berikut ciri-ciri interaksi belajar mengajar:

1. Bertujuan untuk membantu seorang anak dalam perkembangan pengetahuan, keterampilan maupun bakatnya.

2. Perlu adanya suatu alat yang digunakan untuk mencapai tujuan pembelajaran, dan juga bahan-bahan materi berupa media-media pembelajaran yang sudah disiapkan sebelum interaksi belajar mengajar.

3. Aktifitas murid dalam suatu pembelajaran pastinya ada murid yang aktif dan juga yang pasif. Aktif disini adalah giat, baik itu secara lahiriah atau batiniah. Dan apabila jika murid kita pasif kita harus dapat membuatnya jadi aktif, karena dengan berinteraksi dengan guru mempunyai peranan aktif.

Dalam berkomunikasi antara pendidik dengan anak didik ada beberapa hal yang harus diperhatikan yaitu:

a. Menyediakan situasi yang baik

b. Mengikuti irama anak.

Interaksi pedagogik anak berlangsung apabila terdapat beberapa hal sebagai berikut:

a. Rasa tenang pada anak didik 

b. Hadirnya kewibawaan
c. Kesediaan pendidik membantu anak didik
d. Perhatian mutlak anak

Terhadap beberapa langkah yang kemungkinannya dapat digunakan dalam membangun interaksi pedagogik guru dengan siswa, diantaranya pahaman guru terhadap tugas pokoknya dengan utuh, yaitu tidak semata-mata tertumpu pada penyiapan perangkat pembelajaran, tetapi tgas pokok guru dalam pembelajaran adalah membelajarkan siswa sehingga siswa dapat belajar, sementara penyiapan perangkat pembelajaran dan semua yang beraitan dengan itu semuanya merupakan sarana belajar siswa, sehingga siswa dapat belajar lebih maksimal. Secara personal guru harus mendidik siswa dengan rasa cinta dan hati, mendidik dengan hati berarti guru menanamkan komunikasi batin dengan siswa, komunikasi batin dalam pembelajaran memberi dampak jauh lebih dahsyat peranannya dari pada komunikasi yang lainnya. Apalagi bilamana guru dapat berperan sebagai seorang teladan bagi siswa. Karena keteladanan guru bagi siswa merupakan sesuatu konkrit dapat dilihat oleh siswa dalam pembelajaran. ${ }^{4}$

${ }^{4}$ Misdar, M. (2015). Revitalisasi Interaksi Pedagogik Guru dengan Siswa dalam Pembelajaran. Tadrib, 1(2), h. 223-238. 


\section{BAB III \\ PENUTUP}

\section{A. Kesimpulan}

Berdasarkan makalah di atas kami dapat menyimpulkan bahwa:

1. Menurut kamus Besar Bahasa Indonesia Pendidik adalah orang yang mendidik. Pendidik adalah orang dewasa yang membimbing anak agar si anak tersebut bisa menuju kea rah kedewasan. Pendidik merupakan orang yang bertanggung jawab terhadap pelaksanaan pendidikan dengan sasarannya adalah anak didik. Sedangkan, Peserta didik adalah anggota masyarakat yang berusaha mengembangkan potensi diri melalui proses pembelajaran pada jalur pendidikan baik pendidikan informal, pendidikan formal maupun pendidikan nonformal, pada jenjang pendidikan dan jenis pendidikan tertentu.

2. Interaksi secara umum ialah suatu hubungan dalam suatu kegiatan pembelajaran yang dilakukan peserta didik dan pendik untuk mencapai pendewasaan anak dan tercapai tujuan pendidikan, seperti interaksi social.

\section{B. Saran}

Setiap karya pasti mempunyai kelebihan dan juga kelemahan, kami selaku penulis merasa bahwa makalah yang telah dibuat ini masih banyak kekurangannya oleh karna itu penulis senantiasa mengharapkan saran dan kritik yang dapat membangun semangat penulis agar dapat membuat makalah yang lebih baik. 


\section{DAFTAR PUSTAKA}

https://id.wikipedia.org/wiki/Peserta_didik diakses pada 11 April 2021.

https://kbbi.web.id/pendidik Diakses pada 14 Maret 2021.

M. Ramli, Hakikat Pendidik dan Peserta Didik, TARBIYAH ISLAMIYAH, Vol. 5, No. 1, 2015.

Misdar, M. (2015). Revitalisasi Interaksi Pedagogik Guru dengan Siswa dalam Pembelajaran. Tadrib, 1(2)

Zakiah Drajat, Metodik Khusus Pengajaran Agama Islam, Jakarta; Bumi Aksara, 2001. 